\title{
KESIAPAN KERJA SEBELUM DAN SETELAH PRAKTIK KERJA INDUSTRI SISWA SMK DI KABUPATEN BANDUNG
}

\author{
Muhammad F. Rizqi ${ }^{1}$, Inu H. Kusumah ${ }^{2}$, Sulaeman $^{3}$ \\ Departemen Pendidikan Teknik Mesin \\ Universitas Pendidikan Indonesia \\ Jl. Dr. Setiabudhi No. 207 Bandung 40154 \\ fahri.rizqi77@gmail.com
}

\begin{abstract}
ABSTRAK
Tujuan penelitian ini adalah untuk mengetahui kesiapan kerja siswa sebelum prakerin dan kesiapan kerja siswa setelah prakerin selanjutnya mengungkap perbedaan kesiapan kerja siswa sebelum dan setelah melaksanakan prakerin. Metode yang digunakan adalah deskriptif kuantitatif. Populasi dalam penelitian ini adalah siswa kelas XI SMK Bintara kompetensi keahlian teknik kendaraan ringan (TKR) dan sampel berjumlah 61. Instrumen yang digunakan adalah angket yang diberikan kepada siswa sebelum prakerin dan diberikan setelah siswa prakerin. Angket tersebut diberikan untuk melihat peningkatan kesiapan kerja hasil prakerin siswa. Hasil penelitian menunjukan peningkatan hasil kesiapan kerja siswa setelah prakerin dengan presentase $10 \%$. Terdapat perbedaan kesiapan kerja siswa sebelum dan setelah melaksanakan prakerin.
\end{abstract}

Kata kunci: praktik kerja industri, kesiapan kerja, mekanik sepeda motor

\section{PENDAHULUAN}

Kemajuan Ilmu Pengetahuan dan Teknologi dewasa ini mengalami kemajuan yang sangat pesat, dan memberikan peningkatan kualitas dalam persaingan di dunia kerja. Ketatnya persaingan di dunia kerja disebabkan oleh tingginya angka tenaga kerja, sedangkan lapangan pekerjaan yang ada sangatlah terbatas. Persaingan di dunia kerja dapat dihadapi dengan peningkatan kualitas pada Sumber Daya Manusia (SDM). Peningkatan kualitas SDM dapat dilakukan salah satunya dengan diadakannya pendidikan. Sekolah Menengah Kejuruan (SMK) merupakan salah satu lembaga pendidikan yang berupaya untuk membangun SDM yang berkualitas. Tujuan SMK dijelaskan pada Permendiknas bahwa: penyelenggaraan pendidikan SMK bertujuan untuk meningkatkan kecerdasan, pengetahuan, kepribadian, akhlak mulia, serta keterampilan untuk hidup mandiri dan siap kerja sesuai dengan bidangnya. Tujuan lainnya adalah untuk menguasai kompetensi program keahlian dan kewirausahaan, baik untuk memenuhi tuntutan dunia kerja maupun untuk mengikuti pendidikan tinggi sesuai dengan kejuruannya (Kuswana, 2013).

Tujuan SMK di atas dapat disimpulkan bahwa SMK mempersiapkan siswa untuk mampu menjadi tenaga mandiri yang kompeten dalam bidangnya. SMK membekali para lulusannya untuk siap bekerja sesuai kompetensi yang dipilih dan tentu saja dapat bersaing di

\footnotetext{
${ }^{1}$ Mahasiswa Departemen Pendidikan Teknik Mesin FPTK UPI

2 Dosen Departemen Pendidikan Teknik Mesin FPTK UPI

${ }^{3}$ Dosen Departemen Pendidikan Teknik Mesin FPTK UPI
} 
dunia global. Terwujudnya tujuan tersebut maka, sekolah menyelenggarakan berbagai program untuk mendukung proses pembelajaran yang mengarahkan siswa ketertarikannya pada hal-hal yang berhubungan dengan Dunia Usaha/Dunia Industri (DU/DI) (Sudarmanto, 2009).

SMK menyelenggarakan program agar tujuan tersebut tercapai, program tersebut adalah Praktik Kerja Industri (Prakerin) dimana praktik langsung di dunia kerja sesuai dengan kompetensi keahlian yang dikembangkan. Prakerin adalah bentuk penyelenggara pendidikan dan pelatihan keahlian kejuruan yang memadukan secara sistematik dan sinkron dengan program pendidikan di sekolah serta program penguasaan keahlian yang diperoleh melalui bekerja langsung di dunia kerja, terarah untuk mencapai suatu tingkat keahlian profesional tertentu (Arikunto, 2012).

Pelaksanaan Prakerin melibatkan kedua belah pihak yaitu sekolah dan dunia usaha/industri secara sungguh-sungguh serta bertanggung jawab mulai dari tahap perencanaan program, tahap penyelenggaraan, sampai pada tahap penilaian, penentuan kelulusan siswa, dan upaya pemasaran lulusanya.

Tujuan Prakerin sebagai berikut: menghasilkan tenaga kerja yang memiliki keahlian professional (dengan tingkat pengetahuan, keterampilan, dan etos kerja yang sesuai dengan tuntutan lapangan kerja) ; memperkokoh link and macth antara sekolah dengan dunia kerja; meningkatkan efesiensi proses pendidikan dan pelatihan tenaga kerja yang berkualitas profesional; dan memberi pengakuan dan penghargaan terhadap pengalaman kerja sebgai bagian dari proses pendidikan.

Seluruh lulusan bilamana mengikuti program tersebut akan siap memasuki dnuia industri. Pengangguran terbuka dari lulusan SMK, Diploma I/II/III dan lulusan Universitas meningkat. TPT lulusan SMK pada Februari 2014 sebesar 7,21\%, dan naik pada Februari 2015 menjadi 9,05\%. TPT lulusan diploma pada Februari 2014 sebesar 5,87\%, dan naik pada Februari 2015 menjadi 7,49\%. Sedangkan, TPT lulusan universitas pada Februari 2014 sebesar 4,31\%, dan naik pada Februari 2015 menjadi 5,34\%.

Data tersebut menunjukkan lulusan SMK masih dalam puncak TPT tertinggi. Berdasarkan data hasil obsevasi dilapangan diperoleh data lulusan SMK Bintara sebagai berikut: lulusan yang sudah bekerja sesuai dengan kompetensi 52 orang, yang tidak sesuai kompetensi 8 orang, lulusan yang belum bekerja 63 orang dan yang melanjutkan ke perguruan tinggi 5 orang. Kesesuaian dengan tujuan prakerin butir satu setelah dilakasanakan prakerin siswa akan lebih siap menghadapi dunia kerja yang sesuai dengan kompetensi keahlian 
ataupun melanjutkan pendidikan ke jenjang yang lebih tinggi. Sehingga keterserapan dunia kerja semakin tinggi serta tidak ada lulusan yang belum bekerja ataupun bekerja yang tidak sesuai dengan kompetensi keahliannya (Slameto, 2005).

\section{METODE PENELITIAN}

Penelitian ini menggunakan metode deskriptif kuantitatif. Penelitian dilakukan untuk mengetahui nilai variabel mandiri tanpa membuat perbandingan atau menggabungkan antara variable satu dengan yang lain. Data penelitian yang diperoleh dari sampel atau populasi penelitian yang dianalisis sesuai dengan metode statistik yang digunakan. Penelitian ini dimaksudkan untuk mendapatkan data mengenai kesiapan kerja siswa kelas XI Program Keahlian Teknik Kendaraan Ringan SMK Bintara untuk memasuki dunia kerja.

Penelitian dilakukan terhadap siswa di SMK Bintara yang beralamat di Jl. Cikijing Desa Linggar Kec. Rancaekek Kab. Bandung. Sasarannya, yaitu siswa kelas XI Program Keahlian Teknik Kendaraan Ringan. Fokus utama penelitian ini terletak pada kesiapan kerja siswa. Waktu pelaksanaan penelitian ini, yaitu bulan November tahun 2015. Jumlah populasi dalam penelitian ini yaitu seluruh siswa kelas XI TKR SMK Bintara yang terdiri dari 2 kelas dengan jumlah 62 orang. Populasi ini dipilih karena siswa kelas XI akan melaksanakan program prakerin

Sampel penelitian dipilih dengan cara menggunakan teknik sampling Non Probability Sampling (Random Sampling). Sampel yang digunakan yaitu adalah sampel total yaitu kelas XI TKR 1 dan XI TKR 2 yang berjumlah 61 anggota sampel. Instrumen yang digunakan yaitu kuesioner atau angket. Angket digunakan untuk memperoleh data mengenai kesiapan kerja siswa kelas XI

\section{HASIL PENELITIAN}

Hasil perhitungan uji reliabilitas nilainya adalah 0,97 yang termasuk pada kategori sangat kuat. Sehingga dapat disimpulkan berdasarkan perhitungan CVI dan CVR beserta uji reliabilitas maka angket tersebut dapat digunakan dan cocok digunakan untuk mengukur kesiapan kerja.

Perhitungan $\mathrm{N}$-Gain diperoleh sebesar 0,43. Artinya rata-rata peningkatan kesiapan kerja pada siswa sebelum dan setelah melaksanakan prakerin memiliki kategori sedang. Hasil angket nilai kesiapan kerja sebelum prakerin rata-rata 71, termasuk kategori kurang. Nilai kesiapan kerja sesudah prakerin rata-rata 78, termasuk kategori baik. Hasil hitungan untuk 
prosentase menunjukkan terdapat prosentase peningkatan kesiapan kerja setelah prakerin sebesar $10 \%$. Hasil pengujian hipotesis menunjukkan bahwa prakerin membantu siswa dalam mempersiapkan diri dalam memasuki dunia kerja.

\section{PEMBAHASAN}

Kesiapan kerja yang diukur pada penelitian ini adalah kesiapan kerja siswa sebelum melaksanakan prakerin. Masalah yang terjadi dilapangan masih banyak lulusan di SMK Bintara yang belum bekerja, setelah melakukan penelitian tentang kesiapan kerja terbukti bahwa kesiapan kerja siswa sebelum prakerin belum dapat dikategorikan baik yakni dengan rata-rata nilai hasil angket 71 . Data hasil kesipan kerja siswa sebelum praktik industri yang dapat dikategorikan kurang. Kesiapan kerja ini harus dimiliki oleh seseorang yang akan bekerja di dunia industri. Pendidikan kejuruan menyelenggarakan prakerin yang bertujuan untuk memberikan pengalaman kerja kepada siswa sehingga kesiapan kerja siswa dapat ditingkatkan (Majid dan Firdaus, 2014).

Kesiapan kerja yang diukur pada penelitian ini berdasarkan pada kompetensi yang harus dimiliki oleh seseorang yang akan bekerja di industri. Kompentensi yang dimaksud adalah integritas dan kejujuran pada siswa, dapatnya mengendalikan emosinal diri sendiri, adanya pengembangan diri, dapat berorientasi berprestasi, mempunyai keyakinan diri yang baik, dapat berkomitmen dalam berorganisasi, memiliki sikap inisiatif dan proaktif, serta memiliki kreativitas dan dapat berinovasi dan juga memiliki kemampuan kognitif (Primardiana, 2013). Hasil angket kesiapan kerja sebelum prakerin yang berdasarkan teori tersebut mendapatkan hasil dengan kategori kurang.

Kesiapan kerja yang diukur pada penelitian ini adalah kesiapan kerja siswa setelah melaksanakan prakerin. Masalah yang terjadi dilapangan masih banyak lulusan di SMK Bintara yang belum bekerja. Setelah melakukan penelitian tentang kesiapan kerja terbukti bahwa kesiapan kerja siswa setelah prakerin dapat dikategorikan baik yakni dengan rata-rata nilai hasil angket 78. Data hasil kesiapan kerja siswa setelah praktik industri yang dapat dikategorikan baik. Kesiapan kerja ini harus dimiliki oleh seseorang yang akan bekerja di dunia industri. Pendidikan kejuruan menyelenggarakan prakerin yang bertujuan untuk memberikan pengalaman kerja kepada siswa sehingga kesiapan kerja siswa dapat ditingkatkan. 
Kesiapan kerja yang diukur pada penelitian ini berdasarkan pada kompetensi yang harus dimiliki oleh seseorang yang akan bekerja di industri. Kompentensi yang dimaksud adalah integritas dan kejujuran pada siswa, dapatnya mengendalikan emosinal diri sendiri, adanya pengembangan diri, dapat berorientasi berprestasi, mempunyai keyakinan diri yang baik, dapat berkomitmen dalam berorganisasi, memiliki sikap inisiatif dan proaktif, serta memiliki kreativitas dan dapat berinovasi dan juga memiliki kemampuan kognitif. Hasil angket kesiapan kerja setelah prakerin yang berdasarkan teori tersebut mendapatkan hasil dengan kategori baik. Hasil data tersebut dapat disimpulkan bahwa tujuan prakerin tercapai dan siswa setelah prakerin memiliki telah memiliki kompetensi yang harus dimiliki seseorang untuk memasuki dunia industri.

Hasil angket kesiapan kerja siswa sebelum prakerin mendapat nilai rata-rata 71 yang berkategori kurang. Namun, hasil angket kesiapan kerja siswa setelah prakerin mendapat nilai rata-rata 78 yang berkategori baik. Hasil tersebut dapat disimpulkan juga adanya perbedaan kesiapan kerja siswa sebelum dan setelah melaksanakan prakerin. Perbedaan tersebut merupakan perubahan yang baik dari kesiapan kerja siswa menghadapi dunia kerja setelah lulus. Prosentase kenaikannya adalah 10\%, dan berdasarkan perhitungan $\mathrm{N}$-Gain didapatkan nilai rata-rata $N$-Gain=0,43. Nilai $N$-Gain tersebut termasuk pada kategori sedang sehingga dapat disimpulkan peningkatan nilai kesiapan kerja sebelum dan setelah prakerin berkategori sedang.

Data yang diperoleh dapat disimpulkam bahwa kegiatan pelaksanaan Praktik Kerja Industri (Prakerin) pada kelas XI TKR telah mencapai hasil maksimal dan dapat meningkatkan kesiapan kerja siswa untuk memasuki dunia kerja setelah lulus. Hasil tersebut diperoleh dari perhitungan uji $\mathrm{T}$ yang dimana $\mathrm{t}_{\text {hitung }}$ lebih besar dibandingkan $t_{\text {tabel }}$ atau bilamana dibuat angka adalah $\mathrm{t}_{\text {hitung }}=22.68>\mathrm{t}_{\text {tabel }}=1.98$. Data tersebut menandakan adanya perbedaan yang signifikansi tentang kesiapan kerja siswa sebelum dan setelah melaksanakan prakerin di SMK Bintara.

Terdapatnya perbedaan kesiapan kerja siswa ditunjukkan dari adanya integritas dan kejujuran pada siswa, dapatnya mengendalikan emosional diri sendiri, adanya pengembangan diri, dapat berorientasi berprestasi, mempunyai keyakinan diri yang baik, dapat berkomitmen dalam berorganisasi, memiliki sikap inisiatif dan proaktif, serta memiliki kreativitas dan dapat berinovasi dan juga memiliki kemampuan kognitif yang tinggi pada siswa. Prakerin yang diselenggarakan oleh sekolah dapat meningkatkan kesiapan kerja siswa pada kompetensi keahlian TKR. Hasil penelitian ini memberikan beberapa implikasi, antara lain: implikasi 
terhadap kesiapan kerja siswa dari segi kompetensi yang harus dimiliki oleh seseorang yang akan bekerja di industri yaitu memiliki integritas dan kejujuran, dapatnya mengendalikan emosi diri sendiri, adanya pengembangan diri, dapat berorientasi berprestasi, mempunyai keyakinan diri yang baik, dapat berkomitmen dalam berorganisasi, memiliki sikap inisiatif dan proaktif, serta memiliki kreativitas dan dapat berinovasi dan juga memiliki kemampuan kognitif yang tinggi pada siswa. Implikasi terhadap motivasi siswa untuk meningkatkan kesiapan kerja dan implikasi terhadap pengembangan kurikulum pada spectrum kurikulum SMK khususnya kompetensi keahlian TKR.

\section{KESIMPULAN}

Kesimpulan penelitian ini, sebagai berikut kesiapan kerja siswa SMK sebelum melaksanakan Prakerin berkategori kurang. Kesiapan kerja siswa SMK berkategori baik. Terdapat perbedaan peningkatan kesiapan kerja siswa kelas SMK Program Keahlian Teknik Kendaraan Ringan sebelum melaksanakan Prakerin dan setelah melaksanakan Prakerin.

\section{DAFTAR PUSTAKA}

Arikunto, S. (2012). Dasar-Dasar Evaluasi Pendidikan Edisi 2. Jakarta: Bumi Aksara.

Kuswana, S. W. (2013). Filsafat Pendidikan Teknologi, Vokasi dan Kejuruan. Bandung: Alfabeta.

Majid, A. dan Firdaus, A. (2014). Penilaian Autentik Proses dan Hasil Belajar. Bandung: Interes Media.

Primardiana. (2013). Model Evaluasi Pembelajaran Berbasis Kaizen di Sekolah Menengah Atas. Jurnal Penelitian dan Evaluasi Pendidikan.

Slameto. (2005). Belajar dan Faktor-Faktor yang Mempengaruhinya. Jakarta: Rineka Cipta.

Sudarmanto. (2009). Kinerja dan Pengembangan Kompetensi SDM. Yogyakarta: Pustaka Pelajar. 